\title{
Kompetensi Guru dan Kaitannya dengan Pengembangan Materi Ajar Bahasa Indonesia
}

\author{
Ernawati \\ Universitas Negeri Padang (UNP) \\ ernawatiss78@yahoo.co.id
}

Kompetensi guru di Indonesia perlu selalu ditingkatkan apalagi semenjak pandemi covid 19 melanda, hampir semua aktivitas pembelajaran beralih ke non klasikal atau daring. Menurut Agusrida et al. (2020) tampaknya kemampuan guru menggunakan teknologi digital masih rendah sesuai informasi yang didapatkan dari instruktur pelatihan jarak jauh (PJJ) BDK (Balai Diklat Keagamaan) Padang. Hal ini tentu tidak sejalan dengan tuntutan seorang guru professional yakni salah satu kompetensi yang harus dimiliki guru (H. Barringer, R. Kuiper, A. Pnueli (dalam Agusrida et al. 2020)). Agusrida et al. (2020) menyatakan bahwa seorang guru profesional wajib mengembangkan kemampuan profesioanalismenya dengan melakukan tindakan reflektif dan mahir berkomunikasi menggunakan teknologi digital, terutama dalam memilih media dan materi pembelajaran.

Senada dengan pendapat Mulyadi et al. (2020) menyampaikan bahwa pendidik di zaman milenial harus mampu melahirkan media dan sumber belajar yang inovatif, efektif dan berbasis multi media sehingga pembelajaran akan menyenangkan dan memotivasi siswa belajar secara mandiri terutama pembelajaran Bahasa Indonesia. Berdasarkan pendapat Syahrul et al. (2020) mengatakan bahwa model pembelajaran bahasa pada abad 21 ini disesuikan dengan perkembangan ilmu pengetahuan dan teknologi yang sudah semakin pesat maka diperlukan inovasi sesuai kebutuhan siswa yang belajar secara online. Artinya kaitan antara kompetensi guru menggunakan teknologi multi media dengan pengembangan materi ajar terutama materi Bahasa Indonesia saling berkaitan satu sama lain dalam menciptakan pembelajaran yang asyik, menyenangkan, dan mampu meningkatkan prestasi belajar siswa. Seperti yang sudah dilakukan oleh Mulyadi et al. (2020) menyatakan bahwa mereka menggunakan materi pengajaran Bahasa Indonesia dalam bentuk e-modul. Dari hasil penelitian menyatakan e-modul memiliki validitas yang sangat baik, praktis, dan efektivitas. 
Beberapa penelitian tentang kaitan kompetensi pendidik dalam menggunakan teknologi digital dengan pengembangan materi ajar Bahasa Indonesia juga sudah dilakukan oleh Syahrul et al. (2019) yang mendapatkan hasil bahwa guru sudah menggunakan media digital dalam proses pembelajaran namun media yang digunakan masih terbatas dan belum beragam sedangkan dampaknya pada pembelajaran masih ada efek positif negatifnya. Survei tersebut dilakukan kepada sebanyak 112 guru Bahasa Indonesia se-Sumatera Barat. Penelitian yang mirip juga dilakukan Mulyadi et al. (2018) tentang pengembangan e-modul multimedia interaktif pada mata kuliah bahasa Indonesia di IAIN Bukittinggi. Dari penelitiannya menghasilkan e-modul interaktif yang berkualitas sebagai sumber belajar bahasa Indonesia. Sejalan dengan pendapat Faisal (2018) menyatakan bahwa bahan materi yang dibutuhkan siswa berbasis digital salah satunya dengan pengembangan modul. Artinya seorang pendidik khususnya mata pelajaran Bahasa Indonesia yang professional hendaknya mampu menggunakan teknologi untuk menciptakan materi ajar berbasis digital agar proses pembelajaran berjalan menyenangkan, penuh semangat sehingga prestasi peserta didik meningkat.

Sebagai seorang guru profesional harus selalu meningkatkan kompetensinya apalagi dalam penggunaan teknologi digital agar mampu menciptakan media dan materi pengajaran yang interaktif dan menarik. Penggunaan materi pembelajaran Bahasa Indonesia berbasis digital seperti e-modul di era pandemi ini sangat berpengaruh luar biasa bagi peningkatan dan keberhasilan proses pembelajaran siswa yang masih daring atau non klasikal. Pembelajaran lebih interaktif, tidak membosankan, menarik, dan siswa lebih mudah memahami materi yang disampaikan guru. Tentunya hasil belajar dan prestasi peserta didik akan lebih meningkat. Semua itu tidak terlepas dari kemampuan dan ketangkasan guru dalam merancang dan menciptakan materi pengajaran, sehingga menghasilkan proses pembelajaran yang optimal. Jadi kesimpulannya kompetensi guru sangat berkaitan dengan pengembangan materi ajar Bahasa Indonesia.

\section{Daftar Pustaka}

Agusrida, Atmazaki, Syahrul R., Ermanto. (2020). Effectiveness of Online Scientific Publication Training Approach for Teacher's Professional Competence Development at Religious Training Centre in Padang. Jurnal Atlantis Press SARL Advances in Social Science, Education and Humanities Research. Volume 504 (ICoIE 2020). 
Faisal, Achmad. (2018). Pengembangan jobsheet praktikum pemasangan dan pengoperasian sistem kendali. Jurnal Pendidikan Teknologi dan Kejuruan (Vol.8, No.5). Hlm. 370-379). FT UNY.

Mulyadi, M., Atmazaki, A., \& R, S. (2019). The Development of Interacrid Multimedia E-Module on Indonesia Language Course. 178 (ICoIE 2018), 291-

Mulyadi, Syahrul, R, Atmazaki, \& Agustina. (2020). The Development of E- Modules Based on Adobe Flash for Indonesian Subjects at LAIN Bukittinggi. Jurnal af Physics: Conference Series, $1471(1)$.

Novelti, N, Ramadhan, S, Ermanto, E., \& Agustina, A(2018). Developing ad Instructional Mode Assisted Audio Visual Media. Iclle, 263, 111-116.

Syahrul, R, Atmazaki, Sukma, E., \& Indriyani, V. (2021). Multimedia with Socid Learning Networks (SNL): As Learning Innovation in the 4.0 Industrial Era. Jurnal of Physics: Conference Series, 1779(1), 1-9.

Syahrul, R, Sukma, E., \& Indriyani, V. (2019). Teacher competence in utilizing digital media Literncy in education. Jurnal of Physics: Conference Series 1339(1) 